\title{
NEW GENERATION HYBRIDS OF WHITE CABBAGE (Brassica oleracea L. convar. capitata var. alba DC) BASED ON DOUBLED HAPLOIDS
}

\section{V.F. PIVOVAROV, L.L. BONDAREVA, N.A. SHMYKOVA, D.V. SHUMILINA, A.I. MINEIKINA}

All-Russian Research Institute of Breeding and Seed Production of Vegetable Crops, Federal Agency of Scientific Organizations, 14, ul. Selektsionnaya, pos. VNIISSOK, Odintsovskii Region, Moscow Province, 143080 Russia, e-mailvniissok@mail.ru

The authors declare no conflict of interests

Received June 7, 2016

Abstract

Presently, cabbage breeding is mainly focused on $\mathrm{F}_{1}$ hybrids necessitating constant parental lines to be obtained. Doubled haploid (DH) technology based on isolated microspore in vitro culture is widely used to produce pure lines of brassica crops. This method allows us to rapidly develop homozygous lines, in contrast to time-consuming traditional breeding for heterosis in cross-pollinating crops which takes 7 to 10 years for annuals and 14 to 20 years for biennial plants. One of the objectives of DH technology is to provide the all possible number of doubled haploid plants that allows more fully encompass the spectrum of genetic recombination, including the recessive locus. The aim of our study was to evaluate economically important traits in white cabbage (Brassica oleracea L. convar. capitata var. alba DC) constant doubled haploid lines of late ripening and to improve the technology for producing $\mathrm{DH}$ based $\mathrm{F}_{1}$ hybrids. Eleven breeding lines of late ripening cabbage were used to obtain doubled haploid lines from microspore in vitro culture. Of the obtained lines, twelve doubled haploid genotypes were selected for further use based on evaluation of ploidy and combining ability. Seed progeny was reproduced by hybridization of regenerated plants in a climatic chamber (2014-2015). We used the schemes of creating self-incompatible lines and two-line-based hybrids. In the field trials (Moscow region, 2014-2015), the doubled haploids and their hybrid combinations were compared to the standard (Severyanka $F_{1}$ ) for the main valuable characteristics (i.e. the content of dry matter, nitrates, and vitamin C). The field resistance to Fusarium wilt, alternariosis, and pest damage were determined at cabbagehead technical maturity. The resistance to clubroot was assessed under artificial infection. There was a direct relationship of the average number of chromosomes to the number of chloroplasts in the stomata guard cells and the length of guard cells. The frequency of spontaneous doubling of the chromosomes numbers varied from $50.0 \%$ to $87.5 \%$ in different geotypes. A total of 11 to $73 \%$ produced lines were high self-incompatible. Their geitonogamic pollination in the topcrosses resulted in 42 hybrid combinations. The model of $F_{1}$ hybrid most fully responding to consumer market demands was developed. Ten promising hybrid combinations which matched the model parameters in two-year field testing were recommended for variety testing. Hybrids were characterized by uniformity, high biochemical quality, the resistance to major diseases and pests and the yield of $104.60 \pm 8.27 \mathrm{t} / \mathrm{ha}$. The dry matter content reached to $10.5 \%$, the sugar content was about 4.21-5.10\%, and ascorbic acid level ranged from 21.12 to $38.70 \mathrm{mg} \%$. Both the highest level of ascorbic acid $(92.0 \mathrm{mg} \%)$ and the smallest nitrate accumulation $(33 \mathrm{mg} / \mathrm{kg})$ were characteristic of one hybrid combination.

Keywords: white cabbage, Brassica oleracea L., doubled haploid lines, heterosis $\mathrm{F}_{1}$ hybrids, in vitro isolated microspore culture, self-incompatibility, DH-technology, spontaneous doubling, ploidy

The most common culture among plants of the Brassica oleracea L. species is white cabbage due to a complex of biological and economically useful properties. $F_{1}$ hybrids with high market quality and resistance to harmful pathogens are most in demand [1]. At present, the creation of heterosis hybrids of white cabbage is based on cytoplasmic male sterility (CMS) and the crossing of self-incompatible inbred lines. Seeds from the intercross inside the same line are not formed, but crosses with plants of another line give $100 \%$ hybrid seeds. Incompatibility is manifested on the style: incompatible pollen does not germinate at all or the pollen tubes, appearing and reaching the surface of the papilla of stigma, 
curl and thicken [2]. Such lines are propagated and maintained by manual geitenogamic pollination of buds $[3,4]$. The main modern requirements for culture are the storability of cabbage-head, the suitability for mechanized harvesting, resistance to diseases (club root disease, vascular bacteriosis, fusarial head blight, etc.) and pests [5]. Intensive cultivar changing requires the acceleration of the selection process [6].

White cabbage is a cross-pollinated plant with a 2-year growth cycle. In traditional selection, inbred lines of white cabbage are obtained through forced selfpollination for 6-12 generations, which significantly extends the selection process. To speed up the selection, doubled haploids (DH-technologies) are used [7-12], in particular a microspores culture in vitro, which not only ensures the homozygosis of the DH-line, but also enhances morphogenesis by using the entire spectrum of genetic recombinations including recessive traits. The technology is based on the ability of microspores to switch from gametophytic development to sporophyte under the influence of stress factors (high temperature, high osmotic pressure, etc.). Due to sporophyte type division, microspores form embryoids that develop into haploid plants (Hs) or doubled haploids $(\mathrm{DH})[13,14]$, with the involvement of which in the selection of pure lines reduces the time spent on crossing [15]. For vegetable crops, including cabbage, domestic DH-technology [16] has been developed, but it needs to be optimized for specific genotypes.

In plants developed after regeneration from isolated microspore cultures ploidy differs: alongside with doubled haploids, haploids, tetraploids, and mysoploids are presented [17]. In this case only homozygotic diploid plants arising as a result of spontaneous doubling of the number of chromosomes can be directly used in breeding programs [18]. There are several methods for analyzing ploidy. The classical method of chromosome counting in cells of meristematic root tissue or in dividing cells of young buds is most accurate [19, 20]. However, it is very complex and time-consuming and is not suitable for large scale screening [21]. Quantitation of nuclear DNA content and ploidy by flow cytometry [22] is carried out easily and quickly with a minimal amount of leaf tissue, but it requires considerable expenditures for equipment and reagents [23]. The count of the number of chloroplasts in the guard cells of the stomas is considered as a fairly simple and cheap method that can be used for most crops, including cabbage. It is shown that there is a high correlation between the number of chloroplasts in the stomata guard cells and the ploidy of plants [24]. Thus, the optimization of DHapproach for breeding and seed production remains relevant [25-28].

For the first time in Russia, using the culture method of isolated microspores in vitro, we obtained DH-populations of white cabbage, in which forms with predetermined properties were detected, which enabled us to select promising hybrid combinations in a short time.

The purpose of this work was to evaluate the constant lines of white cabbage doubled haploids on a set of agriculturally important traits and to improve the technology for creating heterotic $F_{1}$ hybrids on their basis.

Technique. The lines of doubled haploids were obtained via the isolated microspore in vitro culture using 11 selection lines of late-ripening white cabbage (Brassica oleracea L. convar. capitata var. alba DC). Donor plants were grown in a climatic chamber at $20-22{ }^{\circ} \mathrm{C}$ and $16 \mathrm{~h} / 8 \mathrm{~h}$ (day/night) with illumination of 9000 lux. Buds harvested at the initial stage of flowering were sterilized for $30 \mathrm{sec}$ in $96 \%$ ethanol, then $5 \mathrm{~min}$ in a $50 \%$ aqueous solution of the commercial preparation Belizna (KhimAlians, Russia) with the addition of 1 drop Tween 20 (PanReac Quimica S.L.U, Spain) per $100 \mathrm{ml}$, followed by 3-fold washing in sterile distilled water. Sterile buds $4-5 \mathrm{~mm}$ in size were transferred to Lichter's medium with half concentration of components $\left({ }^{1} / 2 \mathrm{NLN}\right)$ and $13 \%$ su- 
crose, $\mathrm{pH} 5.8$ [29], 30 buds per $6 \mathrm{ml}$ medium, and homogenized. The microspore suspension was passed through a nylon filter with a cell size of $40 \mu \mathrm{m}$ and precipitated for $5 \mathrm{~min}$ at $125 \mathrm{~g}$ in an Eppendorf 5804R centrifuge (Eppendorf AG, Germany). Microspores were washed twice in $1 / 2$ NLN. The washed microspores were placed in Petri dishes of $6 \mathrm{~cm}$ in a diameter $(10$ buds per dish) with $5 \mathrm{ml}$ of the nutrient medium of the above composition and incubated for 2 days in the dark at $32{ }^{\circ} \mathrm{C}$. The incubation was then carried out at $25{ }^{\circ} \mathrm{C}$ in the dark to form embryoids. When the embryoids reached the stage of large globules, the heart-shaped or torpedo phase, they were placed in Petri dishes on Gamborg's medium (B5) [30] supplemented with $0.5 \%$ glucose, $0.5 \%$ sucrose and phytogel $(3 \mathrm{~g} / \mathrm{l})$.

The shoots that embryoids formed were separated, placed on $1 / 2 \mathrm{Mu}-$ rashige-Skoog medium (MS) with $2 \%$ sucrose and $3 \mathrm{~g} / \mathrm{l}$ phytogel, and cultured at $25{ }^{\circ} \mathrm{C}$ and a photoperiod of $14 \mathrm{~h}$ (2500 lux, fluorescent lamps). Plants with normally developed leaves and root system were transferred to vegetation vessels with a mixture of peat and perlite (7:3) and covered with perforated plastic cups for adaptation in vivo. Regenerated plants grown under the same conditions as donor plants [32] were evaluated for ploidy and combination ability.

The number of chromosomes in the cells of the meristematic root tissue was calculated by spreading method. Root tips of $0.5-1.0 \mathrm{~cm}$ in length were placed in a solution of $\alpha$-bromide-naphthalene $(1 \mu \mathrm{l}$ per $10-15 \mathrm{ml})$ and kept for 12 hours in the cold. The roots were then transferred to a Clarke's fixative (alcohol and glacial acetic acid at a 3:1 ratio) and left for 1 hour in the cold, then thoroughly washed in water and transferred to $0.3 \mathrm{ml}$ of a mixture of enzymes ( $10 \mathrm{ml}$ citrate buffer, $\mathrm{pH} 4.5$, cellulase $0.2 \mathrm{~g}$, $5 \mathrm{~S}$ pectinase $0.2 \mathrm{~g}$, macerozyme $0.25 \mathrm{~g}$, dreizelase $0.1 \mathrm{~g}$ ) with the addition of cellulase $0.006 \mathrm{~g}$ and $2.7 \mathrm{ml}$ of citrate buffer. The specimen was covered and put on a water bath $\left(37^{\circ} \mathrm{C}\right)$ for 1 hour. After softening the roots, the enzyme mixture was replaced with water. The white tip of the root was separated and pipetted onto the glass. A drop of acetic acid and a freshly prepared Clarke's fixative were added and the preparation was dried in air. The preparations were examined using an Axio Imager A2 fluorescence microscope (Carl Zeiss, Germany) with filter kits for DAPI (Zeiss Filter set 1, Carl Zeiss, Germany) [33].

For indirect determination of ploidy, chloroplasts were counted in the guard stomatal cells and their length was measured using an Axio Imager A2 microscope (Carl Zeiss, Germany) with fluorescence (filter set BR 490 and 515) [34]. The epidermal layer of cells was removed from the underside of the leaves, washed in distilled water, placed on a slide in a drop of water, covered with a cover slip and viewed under a microscope. Photos of at least 20 pairs of stomatal cells in each plant were used for documentation and chloroplast counting was performed. Visualization, measurements and calculations were carried out using an AxioVision software (Carl Zeiss, Germany).

Seed progenies were obtained by crossing regenerants in an artificial climate chamber during the winter-spring 2014-2015 (under the same conditions as in cultivating donor plants). The scheme for creating self-incompatible lines and obtaining two-line hybrids of white cabbage was used [35]. Field trials with seeds were laid out in 2014-2015 on experimental plots prepared according to standard for vegetable crops [36]. Seeds were sown in the third decade of April in cassettes with a cell diameter of $5 \times 5 \mathrm{~cm}$. In the third decade of May, the seedlings were planted in an open soil per 10 plants in 2 -fold replication. The plantation scheme is $70 \times 50 \mathrm{~cm}$.

At technical ripeness of the head, lines of doubled haploids and hybrid combinations were characterized for a number of agriculturally important traits 
(the weight and size of the head, the diameter of the rosette of leaves, the height of the outer and inner cabbage stump, the size of the leaf), comparing with the standard (Severyanka $F_{1}$ ). The vegetation period was estimated as time for maturing $90 \%$ of the heads, after which the yield was harvested. The location of the lower leaves of the rosette, the color of the leaves, the intensity of the wax coating, the state of the surface of the leaf blade, the venation pattern were assessed visually. Biochemical parameters were determined in the integrated sample of the most typical heads, i.e. dry matter - after drying to constant weight, nitrates - by potentiometry, vitamin $\mathrm{C}$ - iodometrically [37].

Field resistance to fusarium wilt, alternaria, and pest damage were studied under natural field conditions at technical ripeness of the head. Resistance to the club root disease (damage, \%) was evaluated under artificial infection with a randomly distributed placement of plants in 2-fold replication per 10 pcs in each variant [38].

Statistical processing included the determination of the arithmetic mean $(X)$ and the mean error $(m)$.

Results. Among the 10 white cabbage selection lines only 5 lines were responsive to introduction into culture in vitro. As a result, from 20 to 1000 regenerant plants per parent line were obtained from isolated microspores in vitro.

It was found that haploid cells in the in vitro culture were unstable, and tended to endomitosis (doubling of chromosomes without nuclear fission) with formation of cells of different ploidy. This made it possible to divide all the studied samples into groups according to the ploidy in accordance with the proposed indicators (Table 1). It was shown that the frequency of spontaneous doubling of the number of chromosomes in regenerative plants varied from 50.0 to $87.5 \%$ depending on the genotype. In the works of other authors, the doubled haploid frequency in white cabbage was 10-40\% [39], 21-67\% [40], and $50-70 \%$ [41]. In our studies, the proportion of haploid and tetraploid plants ranged from 0 to $25.0 \%$.

1. Ploidy of regenerated plants of late-ripening white cabbage (Brassica oleracea $\mathrm{L}$. convar. capitata var. alba DC) based on the results of cytological analysis $(X \pm m)$

\begin{tabular}{|c|c|c|}
\hline Ploidy & NCGC, psc. & GCL, nm \\
\hline Haploids $(n=9)$ & $9.00 \pm 0.63$ & $20.45 \pm 0.80$ \\
\hline Diploids $(2 n=18)$ & $13.73 \pm 0.80$ & $24.15 \pm 0.55$ \\
\hline Tetraploids $(4 n=36)$ & $24.53 \pm 1.46$ & $34.12 \pm 0.70$ \\
\hline
\end{tabular}

In all variants, we observed a direct relationship between the average number of chromosomes, the number of chloroplasts in the stomata guard cells, and the length of these cells. It is reported that in plants the number of chloroplasts correlates with the number of

chromosomes, that is, the number of chloroplasts in diploid plants is about half as many that in haploids [34]. According to the literature, B. oleracea ssp. plants have the following number of chloroplasts in the stomata guard cells: 6-9 for haploids, 10-15 for diploids, and 20-25 for tetraploids [42]. The results of our studies confirmed that the calculation of the number of chloroplasts could be the simplest and fastest method to estimate plant ploidy.

The scheme we used for obtaining heterosis hybrids $F_{1}$ was based on sporophytic physiological self-incompatibility of the lines of white cabbage doubled haploids. Artificial geitenogamic pollination of flowers, with bud preemasculation, resulted in varying manifestation of self-incompatibility in lines of regenerated plants which was determined by the number of seeds (high for 0 $1 \mathrm{pcs} / \mathrm{seedpod}$, medium for 2-5 pcs/seedpod, low or absent for $>5$ pcs/seedpod). Depending on the genotype, from 11 to $73 \%$ of the lines of doubled haploids 
2. Complex evaluation of the main agriculturally important traits in prospective hybrid combinations based on doubled haploid lines of late-ripening white cabbage (Brassica oleracea L. convar. Capitata var. alba DC) ( $X \pm m$, Moscow region)

\begin{tabular}{|c|c|c|c|c|c|c|c|c|c|c|c|c|c|c|}
\hline \multirow{3}{*}{$\begin{array}{l}\text { Hybrid } \\
\text { combination }\end{array}$} & \multirow{3}{*}{$\begin{array}{l}\text { Vegeta- } \\
\text { tion, days }\end{array}$} & \multirow{3}{*}{$\begin{array}{l}\text { Head } \\
\text { weight, kg }\end{array} \mid$} & \multirow{3}{*}{ Yield, t/ha } & \multicolumn{3}{|c|}{ Stump size, $\mathrm{cm}$} & \multicolumn{4}{|c|}{ Biochemical parameters } & \multicolumn{3}{|c|}{ Plant infection, $\%$} & \multirow{3}{*}{$\begin{array}{l}\text { Pest damage, } \\
\%\end{array}$} \\
\hline & & & & \multicolumn{2}{|c|}{ inner } & \multirow{2}{*}{$\begin{array}{l}\text { outer } \\
\text { height }\end{array}$} & \multirow{2}{*}{$\begin{array}{l}\text { dry matter, } \\
\%\end{array}$} & \multirow{2}{*}{ sugars, $\%$} & \multirow{2}{*}{$\begin{array}{l}\text { vitamin } \\
\mathrm{C}, \mathrm{mg} \%\end{array}$} & \multirow{2}{*}{$\begin{array}{l}\text { nitrates, } \\
\mathrm{mg} / \mathrm{kg}\end{array}$} & \multirow{2}{*}{$\begin{array}{l}\text { club root } \\
\text { disease }\end{array}$} & \multirow{2}{*}{$\begin{array}{l}\text { fusarium } \\
\text { wilt }\end{array}$} & \multirow{2}{*}{$\begin{array}{l}\text { Alternaria } \\
\text { blight }\end{array}$} & \\
\hline & & & & length & width & & & & & & & & & \\
\hline $3-3-3 \times 1-19-1$ & 160 & $2.76 \pm 0.26$ & $78.66 \pm 7.41$ & $4.57 \pm 0.39$ & $5.07 \pm 0.29$ & $4.72 \pm 0.80$ & 10.50 & 5.10 & 38.70 & 81 & $6.3 \pm 0.4$ & $1.5 \pm 0.1$ & $0.6 \pm 0.2$ & $6.5 \pm 1.0$ \\
\hline $2-45-1 \times 1-18-2$ & 165 & $2.72 \pm 0.19$ & $77.52 \pm 5.42$ & $6.80 \pm 0.36$ & $4.60 \pm 0.18$ & $5.93 \pm 0.61$ & 9.00 & 5.00 & 92.00 & 33 & $12.5 \pm 2.7$ & $2.7 \pm 0.6$ & $2.0 \pm 0.5$ & $7.2 \pm 0.7$ \\
\hline $2-45-1 \times 5-13$ & 165 & $3.18 \pm 0.02$ & $90.63 \pm 0.57$ & $9.00 \pm 1.00$ & $4.00 \pm 0.50$ & $7.00 \pm 0.40$ & 9.90 & 4.40 & 35.20 & 59 & $15.0 \pm 1.8$ & $0.5 \pm 0.1$ & $1.5 \pm 0.1$ & $11.8 \pm 2.5$ \\
\hline $3-3-3 \times 2-331$ & 160 & $2.26 \pm 0.18$ & $64.41 \pm 5.13$ & $8.12 \pm 0.55$ & $6.43 \pm 1.02$ & $9.33 \pm 3.79$ & 10.06 & 4.42 & 26.40 & 100 & $25.0 \pm 5.2$ & $5.0 \pm 0.8$ & $3.0 \pm 0.2$ & $7.0 \pm 0.5$ \\
\hline $11-124-1 \times 2-307$ & 158 & $2.41 \pm 0.35$ & $68.69 \pm 9.98$ & $6.26 \pm 1.28$ & $4.57 \pm 0.43$ & $5.36 \pm 0.69$ & 10.13 & 4.85 & 37.60 & 80 & $17.5 \pm 2.2$ & $3.8 \pm 0.1$ & $3.3 \pm 0.2$ & $6.0 \pm 0.2$ \\
\hline $5-13-2 \times 2-307$ & 165 & $2.49 \pm 0.48$ & $70.97 \pm 13.68$ & $6.19 \pm 0.96$ & $4.00 \pm 0.51$ & $6.00 \pm 1.33$ & 9.85 & 4.36 & 21.12 & 124 & $20.0 \pm 4.9$ & $6.6 \pm 0.3$ & $1.6 \pm 0.4$ & $6.6 \pm 0.1$ \\
\hline $3-3-3-2 \times 1-19-2$ & 160 & $3.18 \pm 0.07$ & $90.63 \pm 2.00$ & $7.00 \pm 0.60$ & $5.00 \pm 0.40$ & $10.00 \pm 0.10$ & 9.52 & 4.21 & 24.64 & 69 & $31.0 \pm 2.5$ & $7.5 \pm 0.1$ & $2.5 \pm 0.5$ & $10.0 \pm 1.3$ \\
\hline $2-331 \times 11-1-1$ & 165 & $3.09 \pm 0.34$ & $88.07 \pm 9.69$ & $8.25 \pm 0.53$ & $5.17 \pm 0.34$ & $12.85 \pm 0.99$ & 9.60 & 4.40 & 33.40 & 105 & $15.0 \pm 1.0$ & $3.1 \pm 0.7$ & $2.2 \pm 0.2$ & $3.5 \pm 0.8$ \\
\hline $11-68 \times 5-13$ & 158 & $2.99 \pm 0.28$ & $85.22 \pm 7.98$ & $6.43 \pm 0.29$ & $3.07 \pm 0.29$ & $7.57 \pm 0.96$ & 9.80 & 4.90 & 33.40 & 100 & $38.0 \pm 3.6$ & $5.0 \pm 0.4$ & $3.0 \pm 0.1$ & $10.6 \pm 0.5$ \\
\hline $2-331 \times 5-13$ & 165 & $3.67 \pm 0.29$ & $104.60 \pm 8.27$ & $8.94 \pm 0.40$ & $4.34 \pm 0.29$ & $9.86 \pm 1.99$ & 9.80 & 4.70 & 37.00 & 89 & $7.5 \pm 0.8$ & $1.0 \pm 0.1$ & $0.5 \pm 0.1$ & $6.0 \pm 0.1$ \\
\hline $\begin{array}{l}\text { Severyanka } F_{1} \\
\text { (standard) }\end{array}$ & 160 & $2.98 \pm 0.54$ & $84.93 \pm 15.39$ & $9.00 \pm 0.90$ & $5.00 \pm 0.40$ & $5.00 \pm 0.20$ & 9.00 & 4.10 & 31.70 & 109 & $45.0 \pm 2.7$ & $0.5 \pm 0.1$ & $2.0 \pm 0.5$ & $11.0 \pm 1.5$ \\
\hline
\end{tabular}


showed high self-incompatibility, and from 0 to $29 \%$ - medium self-incompatibility. It was these lines (12 genotypes) that were further used in the creation of heterotic hybrids $F_{1}$ (lines with no self-incompatibility were involved in other breeding programs). As a result of the topcross in the artificial climate chamber, 42 hybrid combinations were obtained on the basis of self-incompatibility.

For further planning experiments, the target model $F_{1}$ of the hybrid was compiled for the main agrotechnical and consumer characteristics. For the model, the vegetation period is 150 days or more (from planting the seedlings to the technical ripeness of the head); heads are equal in maturation terms, transportable, suitable for mechanized harvesting, medium sized, rounded, dense, weighing 2.5-3.5 kg, with excellent internal structure, small internal stump, with dry matter content of 9-10\%, high vitamin $\mathrm{C}$ and sugars level, and low nitrates, resistant to major diseases and pests.

In the complex evaluation of all samples within 2 years, 10 promising hybrid combinations were identified under field conditions by the agriculturally important traits (Table 2). The vegetation of hybrids lasted for 158-165 days, which corresponded to the late maturation period. Yields ranged from $64.41 \pm 5.13$ to $104.60 \pm 8.27 \mathrm{t} / \mathrm{ha}$, which made the cultivation of these hybrids cost-effective. The inner stump was small, that corresponded to the standard pattern, and in most cases inner stump turned out to be almost 2 times smaller than the standard, due to which the eatable part of the head increased. Among the hybrids the samples with high outer stump (from 9.33 \pm 3.79 to $12.85 \pm 0.99$ $\mathrm{cm})$ were detected which made them suitable for mechanized harvesting. All hybrids were characterized by a high content of dry matter (from 9.0 to $10.5 \%$ ). The amount of ascorbic acid ranged from 21.12 to $38.70 \mathrm{mg} \%$. An exception was a hybrid combination $2-45-1 \times-18-2$ with ascorbic acid content of $92.0 \mathrm{mg} \%$, which was almost 3 times higher than in the remaining samples. In the same hybrid combination, the accumulation of nitrates was the lowest (33 $\mathrm{mg} / \mathrm{kg}$ ). In the remaining samples, their amount was from 33 to $124 \mathrm{mg} / \mathrm{kg}$, which did not exceed the MPC $500 \mathrm{mg} / \mathrm{kg}$ for wet weight (GOST R 518092001) of late-ripening white cabbage. Sugar content (4.21-5.10\%) exceeded the standard in all hybrid combinations.

Consequently, all hybrid combinations had high biochemical indices. Therefore, in the analysis it is necessary to proceed from their comprehensive assessment, which also includes productivity and resistance to major diseases and pests. Note that the hybrids remained mostly low-injured by major diseases and pests, which indicates their relative field resistance.

Thus, from isolated microspore culture in vitro, we obtained regenerated plants of white cabbage with different ploidy. There was a direct dependence between the average number of chromosomes and the number of chloroplasts in the stomata guard cells, and also the length of these cells. The frequency of spontaneous doubling in culture varied from 50.0 to $87.5 \%$ and was the largest for doubled haploids. The involvement of homozygotic lines of such haploids in the breeding allowed us to create hybrid combinations of late-ripening white cabbage for a short time (2-3 years), which correspond to the declared requirements of competitive $\mathrm{F}_{1}$ hybrids.

\section{R E F E R E N C ES}

1. Kras he ninnik N.V. Gavrish, 2010, 2: 16-19 (in Russ.).

2. Nakanishi $\mathrm{T}$. An effective time for $\mathrm{CO}_{2}$ gas treatment in overcoming self-incompatible cabbage in Brassica. Plant Cell Physiol., 1973, 14: 837-873.

3. P e a rs o n O.H. Breeding plants of the cabbage group. Bull. Calif. Agric. Exp. Stn., 1932, 532: $3-22$. 
4. Kry u ch k ov A.B. Izvestiya TSKHA, 1972, 1: 124-131 (in Russ.).

5. $\mathrm{P}$ i v o v a rov V.F., S t a r t s e v V.I. Kapusta, ee vidy $i$ raznovidnosti (raznoobrazie $i$ sposoby vyrashchivaniya) [Cabbage: multiplicity of species, cultivars and their cultivation]. Moscow, 2006 (in Russ.).

6. B o n d a r e v a L.L. Nauchnoe obosnovanie i razrabotka sistemy metodov selektsii $i$ semenovodstva kapustnykh kul'tur. Avtoreferat doktorskoi dissertatsii [Fundamentals and developed techniques for Brassica breeding and seed production. DSci Thesis]. Moscow, 2009 (in Russ.).

7. Zhang W., F u Q., D a i X.G., B a o M.Z. The culture of isolated microspores of ornamental kale (Brassica oleracea var. acephala) and the importance of genotype to embryo regeneration. Scientia Horticulturae, 2008, 117(1): 69-72 (doi: 10.1016/j.scienta.2008.03.023).

8. Du nwe 11 J.M. Haploids in flowering plants: origins and exploitation. Plant Biotechnol. J., 2010, 8: 377-424 (doi: 10.1111/j.1467-7652.2009.00498.x).

9. Wi na rt o B., T e ix e i r a d a S i l v a J.A. Microspore culture protocol for Indonesian Brassica oleracea. Plant Cell Tiss. Organ Cult., 2011, 107: 305-315 (doi: 10.1007/s11240-011-9981-z).

10. K i m J., L e e S.S. Identification of monogenic dominant male sterility and its suppressor gene from an induced mutation using a broccoli (Brassica oleracea var. italica) microspore culture. Hortic. Environ. Biotechnol., 2012, 53(3): 237-241 (doi: 10.1007/s13580-012-0091-6).

11. Yuan S.X., Su Y.B., Li u Y.V., Fang Z.Y., Yang L.M., Zhu ang M., Z hang Y.Y., $\mathrm{S}$ u n P.T. Effects of pH, MES, arabinogalactan-proteins on microspore cultures in white cabbage. Plant Cell Tiss. Organ Cult., 2012, 110: 69-76 (doi: 10.1007/s11240-012-0131-z).

12. Gu H., Zhao Z., Sheng X., Yu H., Wang J. Efficient doubled haploid production in microspore culture of loose-curd cauliflower (Brassica oleracea var. botrytis). Euphytica, 2014, 195: 467-475 (doi: 10.1007/s10681-013-1008-x).

13. Shmykova N.A., Shumili na D.V., Su p ru nova T.P. Vavilovskii zhurnal genetiki $i$ selektsii, 2015, 19(1): 111-120 (in Russ.).

14. D e va ux P., P i cke ring R. Haploids in the improvement of Poaceae. In: Biotechnology in Agriculture and Forestry. V. 56. C.E. Palmer, W.A. Keller, K.J. Kasha (eds.). Springer, BerlinHeidelberg, 2005: 215-242 (doi: 10.1007/3-540-26889-8 11).

15. Kas ha K.J., M a lusz y nsk i M. Production of doubled haploids in crop plants. An introduction. In: Doubled haploid production in crop plants: a manual. M. Maluszynski, K.J. Kasha, B.P. Forster, I. Szarejko (eds). Springer Netherlands, 2003: 1-4 (doi: 10.1007/978-94-017-1293-4_1).

16. Shm y k va N.A., S u pru nova T.P., Pivova rov V.F. Biotechnologies and molecular methods in vegetable crop breeding (to $95^{\text {th }}$ Anniversary of VNIISSOK). Agricultural Biology, 2015, 50(5): 561-570 (doi: 10.15389/agrobiology.2015.5.561eng) (in Engl.).

17. Mo nak hos S.G. Kartofel' $i$ ovoshchi, 2014, 9: 34-35 (in Russ.).

18. R e z n i k ova S.A. Tsitologiya i fiziologiya razvivayushchegosya pyl'nika [Cytology and physiology on developing anther]. Moscow, 1984 (in Russ.).

19. S a ri N., A b a k K., P it r a t M. Comparison of ploidy level screening methods in watermelon: Citrullus lanatus (Thunb.) Matsum. and Nakai. Scientia Horticulturae, 1999, 82: 265-277.

20. Q in X., Rotino G.L. Chloroplast number in guard cells as ploidy indicator of in vitrogrown androgenic pepper plantlets. Plant Cell Tiss. Organ Cult., 1995, 41(2): 145-149.

21. H a m a o k Y., Fuj it a Y., I wa i S. Nimber of chloroplasts in haploids and diploids produced via anther culture in Brassica campestris. Plant Tissue Culture Letters, 1991, 8(2): 67-72.

22. Galbraith D.W., La mbert G.M., Mac as J., D o le ze 1 J. Analysis of nuclear DNA content and ploidy in higher plants. Current Protocols in Cytometry, 2001, 2(7.6): 7.6.1-7.6.227 (doi: 10.1002/0471142956.cy0706s02).

23. Hcini K., Walker D.J., Gonzales E., Frayssinet N., Correal E., Bou $\mathrm{z}$ id S. Estimation of nuclear DNA content and determination of ploidy level in Tunisian populations of Atriplex halimus L. by flow cytometry. In: Flow cytometry - recent perspectives. I. Schmid (ed.). InTech, Rijeka, Croatia, 2012: 103-118 (doi: 10.5772/37955).

24. Wi narto B., Mattjik N.A., Purwito A., M a rwoto B. Ploidy screening of anthurium (Anthurium andreanum Linden ex André) regenerants derived from anther culture. Scientia Horticulturae, 2010, 127(1): 86-90 (doi: 10.1016/j.scienta.2010.09.004).

25. Friedt W., Z a rhloul K. Haploids in the improvements of Crucifers. In: Biotechnology in Agriculture and Forestry. V. 56. C.E. Palmer, W.A. Keller, K.J. Kasha (eds.). Springer, BerlinHeidelberg, 2005: 191-213 (doi: 10.1007/3-540-26889-8_10).

26. Smykalova I. Vetrovcova M., Klima M., M a chackova M., Griga M. Efficiency of microspore culture for doubled haploid production in the breeding project «Czech Winter Rape». Czech J. Genet. Plant Breed., 2006, 42: 58-71.

27. Fe rrie A.M.R., C a s w e 11 K.L. Isolated microspore culture techniques and recent progress for haploid and doubled haploid plant production. Plant Cell Tiss. Organ Cult., 2011, 104: 301309 (doi: 10.1007/s11240-010-9800-y).

28. Takahat a Y., Tak ah a sh i Y., Ts uw mot o R. Microspore culture and doubled haploid. In: Biotechnology of Crucifers. S.K. Gupta (ed.). Springer, 2013: 45-62 (doi: 10.1007/9781-4614-7795-2_4). 
29. Li c ht e r R. Induction of haploid plants from isolated pollen of Brassica napus. Z. Pflanzenphysiol., 1982, 105: 427-434.

30. G a m bo rg O.L., Mille r R.A., O ji m a K. Nutrients requirements of suspension cultures of soybean root cells. Exp. Cell Res., 1968, 50: 151-158 (doi: 10.1016/0014-4827(68)90403-5).

31. Murashige T., Skoog F. A revised medium for rapid growth and bio assays with tobacco tissue cultures. Physiologia Plantarum, 1962, 15: 473-497 (doi: 10.1111/j.1399-3054.1962.tb08052.x).

32. Shumilina D.V., S h my kova N.A., B ond a reva L.L., S u p ru nova T.P. Izvestiya $R A N$, 2015, 4: 368-375 (doi: 10.7868/S000233291504013X) (in Russ.).

33. Pukhal'ski i V.A., Solov'ev A.A., B a daeva E.D., Yurtsev V.N. Praktikum po tsitologii $i$ tsitogenetike rastenii [Plant cytology and cytogenetics - practical works]. Moscow, 2007 (in Russ.).

34. Monakhos S.G., Nguen M.L., B e zbozhnaya A.V., Mon akhos G.F. A relationship between ploidy level and the number of chloroplasts in stomatal guard cells in diploid and amphidiploid Brassica species. Agricultural Biology, 2014, 5: 44-54 (doi: 10.15389/agrobiology.2014.5.44eng) (in Engl.).

35. Monakhos G.F., Mo nak hos S.G. Kapusta pekinskaya Brassica rapa L. Em. Metzg. ssp. pekinensis (Lour.) Hanelt. Biologicheskie osobennosti, genetika, selektsiya i semenovodstvo [Brassica rapa L. Em. Metzg. ssp. pekinensis (Lour.) Hanelt. - biology, genetics, breeding and seed production]. Moscow, 2009 (in Russ.).

36. Dospekhov B.A. Metodika opytnogo dela [Experimental techniques]. Moscow, 1985 (in Russ.).

37. Sapozhnikova E.V., Do rofe e va L.S. Konservnaya $i$ ovoshchesushil'naya promyshlennost', 1966, 5: 29 (in Russ.).

38. Kvas nik ov B.V., A n t o n o v Yu.P. Zashchita rastenii, 1972, 9: 16 (in Russ.).

39. H a n s e n M. Production of homogeneous varieties in Brassica. Modern plant Breeding. Proc. NJF Congress: Agriculture and Society. Norway, Aas (28 Jun-1 Jul 1999). Nordisk Jordbrugsforskning (Denmark), 1999, 81(3): 148-153.

40. Rudolf K., B o hane c B., Hanse n M. Microspore culture of white cabbage, Brassica oleracea var. capitata L.: Genetic improvement of nonresponsive cultivars and effect of genome doubling agents. Plant Breeding, 1999, 118: 237-241 (doi: 10.1046/j.1439-0523.1999.118003237.x).

41. Baidina A.V., Monakhos S.G. Selektsiya kapusty na baze udvoennykh gaploidov. Kartofel' i ovoshchi, 2015, 11: 39-40 (in Russ.).

42. D i a s S.J.C. Protocol for broccoli microspore culture. In: Doubled haploid production in crop plants: a manual. M. Maluszynski, K.J. Kasha, B.P. Forster, I. Szarejko (eds). Springer Netherlands, 2003: 195-204. 